\title{
An Analysis on Social and Individual Harmony in A Farewell to Arms-From the Perspective of Ecofeminism
}

\author{
Bingjie Luo \\ School of Foreign Languages, Southwest Petroleum University, Chengdu, Sichuan, China
}

\begin{abstract}
Ecofeminism is the third wave of feminism after the first wave of feminism - liberal feminism in the 19th century and the second wave of feminism - radical feminism in the 1960s and 1970s[8]. Ecofeminism-the combination of the ecological environment movement and the feminist movement emphasizes the study of the internal relationship between the women oppressed by the patriarchal society and nature ruled by it. With the continuous development of industrial civilization, in the modern society, in order to develop social economy, human beings grab a large amount of natural resources resulting in that the growth and recovery of natural resources cannot keep pace with the speed of acquiring resources. While people seizes resources, waste gas, waste water and other pollutants produced by industrial and agricultural production are discharged into the nature, which seriously pollutes the natural environment, reduces the biodiversity and destroys the ecological balance. Such behavior further intensifies the contradiction between human and nature. We value the relationship between women and nature because there are certain commonalities between them. First of all, as the subject of procreation and rearing, women bear children with their own bodies. And we usually call nature as "mother", endowing it with female characteristics. It is the creator of living things. It constantly produces resources needed by all living things on the earth and feeds everything with its own body. In this way, women are in accordance with nature. Secondly, in the patriarchal society, both of them are the objects of oppression hence there is an intrinsic bond between them. In this paper, the author analyzes the change of the relationship and the change of psychology between the hero Henry and the heroine Catherine in war background and in natural background which is destroyed by human. Meanwhile, the relationship between social environment and natural environment itself also is being pointed out. In such a way, the author intends to arouse the awareness of readers that the importance of achieving harmony between men and women as well as keeping balance between nature and the society, thus human beings may eventually find an approach to this haunting dilemma.
\end{abstract}

Keywords: Ecofeminism, Harmony, The psychological process, Nature, War.

\section{Introduction}

In this part, there are two parts. In the first part, the essential information of Hemingway is introduced. Then the readers can have a better understanding of the writing background of Hemingway.

In the second part, some different comments on this novel are introduced. But the writer has different view from it and will explain it in the following part of this thesis.

\subsection{Ernest Hemingway and His Literary Achievements}

As the saying goes, a hero is nothing but a product of his time. Each literature work will reflect one situation of that era. Only when we understand the background information, can the readers have a better understanding of purpose, reasons and theme which the writer wants to convey.

At the beginning of the 20th century, the United States has just experienced the First World War and Americans are filled with anxiety and panic without any hope for the future. This generation of young people at that time was known as the "lost generation". Their spirit is very terrible, and as described in general is full of confusion.

Ernest Miller Hemingway is an American journalist, novelist and one of the winners of the Nobel Prize in literature. In 1926, a successful novel The Sun also Rises was published. In 1929, A Farewell to Arms, a lengthy and monumental account of the WWI brought fame to the author. In the early 1930s, Hemingway traveled in Africa. In 1935 he wrote The Green Hills of Africa and some other short stories. In 1937, he published the novel The Rich and the Poor, a description of maritime smuggling between the US and Cuba. As a reporter, he went to the front three times in the Spanish civil war, wrote the script "The Fifth Column" in the fire, and created the novel For Whom the Bell Tolls (1940), which took the American's participation in the Spanish people's anti-fascist war as the theme. He donated himself to the struggle of the Spanish people with many famous American writers and scholars. Later, as a war correspondent, he went back to Europe and participated in many battles. When the war was over, he focused his full mind to write in Cuba. In 1952, The Old Man and the Sea was highly acclaimed and Hemingway won the Pulitzer Prize the next year. In the end, he won the Nobel Prize for literature in 1954.

In the process of writing, Hemingway has several writing style. He expresses profound meaning in the simplest words which we call as "Iceberg Principle". And he tends to portray "Code Heroes" who are tough and courageous. They can endure suffering and are not afraid of failure and death. In that confusing and terrible time, such an image show that people with new spirit refused to submit to fate. Another important element that runs through his works is his attitude towards women and towards ecology which were called Ecofeminism. Such element especially is reflected in his famous novel A Farewell to Arms. The author will analyze the application of this theory in this article in detail in the following chapters.

\subsection{The Literature Review of A Farewell to Arms}

Different people's opinions vary from one to another due to their different research fields. 
The people analyzing A Farewell to Arms from perspective of narrative arts focus on the using of the first-person narration "I" in the text. Hemingway combined two "I"-"experiencing I" and "narration I" together, which reduces the distance among the author, narrator, characters and readers but which makes the narration get subjective. In order to avoid this problem, Hemingway uses the Iceberg principle that is "Hiding a lot of content between the lines of a text is like hiding seven eighths of an iceberg under water"[9].

Besides, there are a group of people especially emphasize on the aspect of Anti-war influence. They hold the view that the wars not only badly do harm to people's body, but also leave people with serious psychological trauma which affects the rest life of the participant and distorts people's values and the human nature in such an in different condition[4].

But Chen Fei pays more attention to natural symbolism in this text. He said, "The combination of symbolism with death creates a powerful unity to the novel. The deaths are foreshadowed by the rain, which is used as a substitute for emotion"[2]. Indeed, some images are repeatedly used in this novel to create a specific atmosphere, such as the image of "rain", which creates a bleak atmosphere for the novel and serves as a foil for people's inner numbness and indifference in the endless war[1].

While Xiong Xia uses the theory of Humanism to analyze this text. She points out that the destruction of human beings by war, the pity of ordinary people in war, and the hope that the humanitarianism that symbolizes peace will evoke the conscience in the hearts of people[12]. However, as for the author, she tends to analyze this novel from the perspective of Ecofeminism. The balanced relationship of the women and nature should be pointed out with the development of the society.

\section{The Summary of Ecofeminism}

The first section introduces the reason why the writer wants to do this research. The second section introduces the definition, development history of Ecofeminism and the similarities and differences with other feminist theories. Then the readers will have a better idea of this theory.

\subsection{The Reason for the Applying of Ecofeminism}

The reason why the writer wants to do this research is because in the literature research, the author finds that few critics used the ecological feminism theory to interpret novels. And people do not realize how important the harmony and balance between men and women are in social environment and natural environment, which leads to the original intention of doing research.

\subsection{The Origin and the Definition of Ecofeminism}

Ecofeminism was born in the late 1970s and came to a climax in the 1990s. The work, usually attributed to a French woman, published in the 1970s, prepared the movement for hard cultural and theoretical work. The term Ecofeminism first appeared in two works published in the 1970s by French writer Francoise D'Eaubonne-Le Feminisme ou la Mort, 1974 and Ecologie Feminisme: Revolution ou Mutation. 1978. Although the theory and practice of eco-feminism have made great progress in the 30 years after the publication of her works, her works are still regarded as the important forerunner of western eco-feminism.

In the following years, there are many other feminist theories. But Ecofeminism is still popular. What is Ecofeminism? Ecofeminism refers to a term to criticize the traditional dualistic thinking mode of human/nature and man/woman, and to oppose various forms of domination and oppression. Ecofeminists believe that man and nature, man and woman, and man and society are independent and interactional. In China, there is also a prevailing of Ecofeminism. Liu Wenyuan points out that "Chinese scholars have already begun to try to use the theory to analyze some Chinese works and the research into the actual issues concerning environment..."[5]. That is, the world literature is interlinked.

There are many other kinds of feminism like liberal feminism, radical feminism and Marxist feminism. The most apparent similarity of these feminism theories is that they all focus on the equality between men and women and the liberation of women. Naturally, there are also distinctions among them. Liberal feminism tends to focus on public rights-the aspects of women's political rights, educational chance and economical field. And they think that the social laws should be made to protect their rights. Radical feminism underlines that they should use revolutionary way to solve the gender inequality. Nonetheless Marxist feminists give a new understanding on private property and the gender division[7]. They think that the source of women oppression is the private property in capitalist society. However, what ecofeminists pay attention to is the relationship between men and the nature, women and men, the society and nature. In A Farewell to Arms, Henry and Catherine are in the environment of war and the destroyed natural environment. Using the theoretical way of Ecofeminism, the readers could have a better idea of how to achieve the balanced relationship among individuals and the harmony in society and nature.

\section{The Analysis of A Farewell to Arms}

Character is one of the most fundamental elements in a novel. What they see, what they say, what they hear and the feeling of them, basically all constitutes an entire novel. They have the function of concatenating the whole story and promoting the development of the story. Next, the author mainly analyzes the psychological change process of the hero and heroine from the angle of ecological feminism.

This novel was setting in WWI. As an American teenager, Frederick Henry was an ambulance driver in the WWI in northern Italy and met Catherine Barclay, a British nurse. After wounded by a shell at the front, Henry was taken to the Milan hospital in the rear. Catherine also came to Milan because of the lacking of nurses. They met again. Henry lost himself heart to Barclay this time.

During in the hospital in Milan, the two had a good time and Catherine was pregnant. Returning to the front, Henry found the Italian soldiers lost their spirits and defeated by Germans. Then the soldiers were anti-war. Once in front of a bridge, the 
Italian army police began arresting deserters on the front line. When the soldiers questioned others, Henry escaped from execution by jumping into the river.

He finally traveled to Milan and found Catherine in a small border town. Then they were happily together again. But they were chased by Italian police, who forced them to flee to Switzerland in which Henry and Catherine had a happy time. Unfortunately, Catherine died for childbirth, leaving Henry alone in exile.

\subsection{The Change Process of the Heroine Catherine's Psychology}

In this novel, Catherine, as an English nurse, also experienced several psychological changes in the war. At first, she joined the army with her fiancé and resolutely followed him to the front line as a nurse. It was her complete devotion to love, but then her fiancé died in battle. She wanted to cut off her hair to express her despair and disappointment in love and to express her determination and grief which also existed in our traditional Chinese poetry. Her mind was painful during this time. Until she met Henry, her mind changed again. Henry had tried to kiss her since he had met several times, but Catherine beat him so hard. While the next second she was immersed in Henry sweet talk and hugged him. In the process, it is easy to see that Catherine has begun to look forward to loving again. And she quickly depended on this man. Hemingway wrote such a dialogue "You could not have sent me a note?" "No," "You ought to have let me know, darling"[3]. After she did not see Henry for a few days, she would miss him so much. Then after Henry was injured in hospital, she stayed overnights to take care of Henry for several days. Until her colleague Fergson asked Henry to take a rest for fear that Catherine would not be able to hold on to it. After Henry went back to the front line, he dreamed that Catherine said that she came whenever he wanted her. From such a dream, the readers could know how Catherine is depended too much.

It was seen here that Catherine was deeply involved and obeyed Henry's demands. Even more, Henry fled from the front line, and after a quiet period of time, when she learned that Henry was going to be arrested, she, regardless of her pregnancy for several months, fled with Henry. And in the course of escape, seeing Henry rowing tired, regardless of her physical discomfort and the cold weather, she helped Henry rowing. Finally, at the end of the day, when she was dying, she did not care about her own life, but thought of Henry. All this shows Catherine is depended on Henry too much without much carefulness of her own. However, the female image reflected by Catherine psychological change is not advocated by eco-feminism. In the view of eco-feminists, women should be independent and have their own ideas[11].

In fact, women like Catherine, on the surface, are beautiful and smart, but in the heart, they just want to want to be accessories of men. They have no ideas of their own. There is a description "Of the others one smiled us and put out her tongue and fluttered it up and down"[3]. When these girls from the soldiers' whorehouse see soldiers, in order to get a ride they are flirting. In fact, such a woman is the product of the incessant age of war. In such turbulent times, men, as the main combat forces, went to battle and stormed into battle. For a long time, they were under great mental and physical stress, and their lives were boring. These beautiful girls became a pastime tool for the soldiers, just for a physical relaxation without emotional communication. And women themselves because of the war, distorted values and other reasons are also willing to fall. There was such a phenomenon.

From the perspective of Ecofeminism, Catherine existed in such a war situation in which the society was turbulent and the soldiers were the most important force. Naturally, the patriarchy was prevailing. In such a society, women apparently could not have their own ideas and depended on men to survive. When the war tended to peace and the surroundings was better, the relationship of the individuals would be better. And the balanced relationship between individuals and the society would more easily be achieved.

\subsection{The Change Process of the Hero Henry's Psychology}

In this novel, Henry, as an American teenager, volunteered to serve as an ambulance driver during WWI in northern Italy. $\mathrm{He}$ has also experienced several psychological changes, which are explained in two different ways. In terms of his attitude to war, as a youth in the new era of the United States, he was full of passion and fantasy about war before he joined the army, but there was little writing in the book depicting Henry. But he said several times about his grandfather's money order that his grandson was a patriot, reflecting on the side that it was a glorious thing for those who were not at war. But after the war, Henry's psychology changed a lot, there is a description in novel that "At the start of the winter came the permanent rain and with the rain came the choler. But it was checked and in the end only seven thousand died of it in the army"[3]. From this depicting, the readers could know how indifferent Henry had become. Being faced with such a tragedy, he used the words "only" to describe died men. And in one morning, the shells woke him up. Without fear, he drank a cup of coffee slowly. Then later, one day, when he wrote a report in room, he thought that "I knew I would not be killed. Not in this war. It did not have anything to do with me. It seemed that no more dangerous to me myself than war in the movies"[3]. The war was irrelevant to Henry and he had no feeling. After he faced the fire and the bloody death, his view of life began to change. Every day he has no enthusiasm, no dreams, and every day he lives in confusion. Every day, like other soldiers, he escapes spiritual emptiness and confusion by drinking. During this time, he did not love Catherine, but Catherine was just as a remedy for spiritual emptiness. There is a description that "I knew I did not love Catherine Barkley nor had any idea of loving her. This was a game, in which you said things instead of playing cards"[3]. He thought that the relationship with Catherine was a bridge game and every step of the game he saw clearly.

After he was wounded, he became tired of war, which laid the groundwork for his subsequent defection. He was hurt because when he and his comrades were eating cheese in the trenches and suddenly was attacked by enemy artillery shells. The injury was purely an accident and did not contain any admirable, eulogizing elements. But he won him a silver badge of honor. After he was in hospital, his friend came to see him and assured him that he would be given a silver medal 
because of his serious injury and the success of the war. Such an absurd honor made Henry saw the falsity of war. This brought his feeling of war to a loathing level.

But in this time, Henry got his love. When he was in bed in pain, he felt boring and lonely. Catherine's company and care made Henry truly fall in love with Catherine and had a happy and wonderful time in Milan. During this time, Henry became happy and satisfied, Catherine gradually became his spiritual sustenance, even after he returned to the front line, he often dreamed of her, even when his friends teased Catherine, he was angry. This is quite different from the previous attitude. When his friends teased Catherine, he turned a deaf ear. It showed that his heart had become more positive. Unfortunately, Catherine was died of the pregnant dystocia and their kid also could not live. Henry's life became hopefulness again.

Actually, Henry's psychological process is influenced by nature, the society and woman. When he was in the front line, what he saw was the polluted nature in which dust pervades the air and leaves. The natural environment was terribly destroyed by the human behaviors. In such an environment, Henry could not keep a good psychological situation. Thus, when he escaped to the small town Montreux in which the natural environment did not be polluted, he felt relaxed. Why was the nature contaminated? Because the war destroyed it. In the final analysis, the social element is the most important one. Besides, the change of the attitude towards to Catherine also affected his psychological process. When he regarded Catherine just as sexual partner, his heart was empty. But when he treated her as a kind of spiritual sustenance and fell in love with her, he became satisfied and fulfilled. Therefore, we should analyze character's psychological process from the perspective of Ecofeminism. Then the readers could have a better understanding of the image of the hero. When the war tended to be peaceful and the surrounding was better, the relationship of the individuals would be better. And the balanced relationship among individuals and the society would more easily be achieved.

\subsection{The Achieving of Balance between Nature and Society}

Actually, the natural environment is decided by the situation of the society. If the society is peaceful and harmonious, people will try their best to keep such a balance. So, when they use the natural resources, they will not pollute and badly destroy nature as much as possible. In such a harmonious society and beautiful natural scenery, the relationship of individuals will also be better. As the saying goes, "The better scenery, the better feeling". By contrast, if the society is turbulent and dangerous, what people focus on is the surviving of their own. At this time, they are selfish. They do not care if they destroy the environment or not, break the ecological balance and distort values to get as much resources as possible and build beneficial relationships. Thus, the analysis of a novel should follow the rule of Structuralism just like Liu Dongmei points out that "Structuralism is the belief that things cannot be understood in isolation-they have to be seen in the context of the larger structures they are part of'[6].

In A Farewell to Arms, the natural environment was destroyed by war. Trucks and cars carrying quartermaster supplies and personnel come and go. It has been mentioned many times that dust is scattered all over the leaves and the environment is depressing. And there are many comparisons of environmental descriptions. The description is as follows: "In the bed of the river there were pebbles and boulders dry and white in the sun and the water was clear and swiftly moving and blue in the channels"[3]. But the next description is that "The trunks of the trees too were dusty and the leaves fell early that year and we saw the troops marching along the road and the dust rising and leaves"[3]. This contrast was to set off the destruction of the environment caused by human activities. In addition to cars, there are trenches to be dug for war. From time to time enemy shells destroyed the whole country. These human activities have caused serious damage to the natural environment. And in such a volatile and dangerous environment, people are in danger and endure the heart of suffering every day. It was impossible for Henry to think about his love in such a dangerous environment. So after meeting Catherine in the early days, he only regarded his relationship with Catherine as a game which is as a condiment in dull and numb life. While he was recovering, he was in a relatively quiet and peaceful environment. Slowly calming his heart, he began to seek spiritual sustenance. In the meantime, his relationship with Catherine was truly established. At the end of the story, they lived in a peaceful town Montreux whose life was peaceful and the natural scenery was beautiful. In this place, Henry and Catherine had their best time in their life and the relationship between them reached the highest balanced level. Unfortunately, such a harmonious life in war time just was temporary. Finally, Hemingway pulled people back to the reality. Last, Catherine as Henry's spiritual pillar died causing Henry to live alone forever.

\section{Conclusion}

As a theory of literature, Ecofeminism tends to analyze the things from the aspect of women and advocates the equality of men, women and the whole society. In A Farewell to Arms, Hemingway mainly describes the psychological change process of Catherine and Henry from perspective of Ecofeminism to let us know how these two persons influenced each other and how their relationship is evenly achieved in the war environment. Although as for herself, she is not a perfect one, her carefulness, beautiful appearance and the loyal to love change Henry from an indifferent one without any hope for life to an emotional one who is filled with hope for future and finally make Henry a more balanced one. Thus, both of them achieve harmony in the relationship between men and women, individuals. In the war, human beings took full advantages of nature resources and polluted the surroundings making the countries full of dust. The sky was also never blue again. Besides the terrible nature surroundings, the society was full of tense atmosphere. In such an environment, the balanced relationship among individuals could not be achieved. Not to mention the harmony among society, human beings and nature.

From the psychological change process of Catherine and Henry, we can draw a conclusion that the society is more harmonious and peaceful with a complete social system and a fair institution. For example, we must see the ability of women and the fair employment system should be set to protect women's basic rights. Then the natural environment is 
better. As for the contradiction between nature and the society, the whole society should insist on sustainable development dealing with the relationship between economic development and environmental protection. The society is more peaceful, the environment is better and the living condition of women is better. Thus the social and individual harmony will be achieved.

\section{References}

[1] Aihong Li. Analysis of Three Pairs of Symbolic Meanings in A Farewell to Arms[J]. Journal of New Silk Road, 2017, 23(10): 147, 2017.

[2] Chen Fei. Natural Symbolism Used in A Farewell to Arms[J]. Journal of Overseas English, 2016, 23(2): 157-158.

[3] Hemingway, E. M. A Farewell to Arms[M]. Scribner's Magazine, America, 1929.

[4] Jiang Wang, Li Zou. Mortal Wounds: A Study of trauma themes in A Farewell to Arms[J]. Journal of World Literary Review, 2012, 23(1): 186-188.

[5] Liu Wenyuan. The Study of Ecofeminism and Its Localization[J]. Journal of Academics, 2016, 23(9): 293-298.

[6] Liu Dongmei. An Analysis of A Farewell to Arms in Terms of Structuralism[J]. Journal of Overseas English, 2013, 23(14): 204-205.

[7] Lu Zhong. Evolution and challenge of Marxist Feminism[J]. Journal of Journal of Northeastern University (Social Sciences), 2017, 23(19): 634-642.

[8] Li Jin. Eco-feminism[J]. Journal of Foreign Literature, 2004, 23(5): 57-64.

[9] Svoboda, F. J. Hemingway and The Sun Also Rises: The Crafting of a Style, University Press of Kansas, Kansas, 1983.

[10] Val Plauwood. Feminism and the Mastery of Nature[M]. Trans. Ma Tianjie, and Li Lili, Chongqing Publishing House, Chongqing, 2007.

[11] Weng Xin. Catherine in A Farewell to Arms: Not a Perfect Woman in a Feminist World[J]. Journal of Overseas English, 2017, 23(11): 178-180.

[12] Xia Xiong. On Humanitarianism in A Farewell to Arms[J]. Journal of The Exam Week, 2014, 23(12): 12-13. 